\title{
Will High Technology Save Higher Education From Decline?*
}

\author{
MICHAEL L. SKOLNIK†
}

Canadian higher education has in the past few years succumbed to a mood of despair and defensiveness. Until just a few years ago, it was characterized by a confident, forward-looking energy, secure in the notion that it was the preeminent engine of national development. Since then, we have seen our relative salaries decline; our plant, equipment, and libraries erode; our jobs threatened; and the value of our contribution to Canadian society severely questioned. A number of explanations could be given for this dramatic reversal of our fortunes, with emphasis ranging from demographics to poor public relations, from economic stagnation to short-sighted political manoeuvering. One popular explanation is that Canadian higher education is now (justly) paying off debts it incurred in a Faustian compact with homo economicus. We financed our tremendous growth of yesteryear, this explanation purports, on promises of contributing substantially (or worse, by ourselves, delivering) unprecedented economic growth and industrial expansion. Now that industrial expansion has come to a standstill (and even declined), the primary case for generous funding of higher education is at best called into question, and at worst severely undermined.

For those who accept this retributional explanation of the cause of the current crisis of finance and purpose in higher education, Global Stakes, will likely be perceived as one of the most exciting and optimism-creating books to come along in several years, and one which may galvanize a new sense of purpose and direction among the scientific and technological sectors of higher education. Reactions to this book in the higher education community as a whole, however, are likely to be extreme. Others may dismiss it as merely self-serving advancement of a computer/electronics lobby or pandering to the wishful fantasies of engineering deans. Humanists and classicists may (for reasons suggested by the authors) be simply bewildered by it, or wonder if the cure advanced in this book is worse than the present illness in higher education.

The major premise of Global Stakes is that industrialism is presently at the threshold of a new era in which the dominance of the capital-intensive, physical-

\footnotetext{
- This special feature article is an expanded critical analysis of the book entitled Global Stakes: The Future of High Technology in America, authored by James Botkin et al., and published by Ballinger Publishing Company, Cambridge, Massachusetts, 1982.
}

† Chairman, Higher Education Group, Ontario Institute for Studies in Education. 
resource-based economy of the past will give way to a knowledge-intensive, human-resource based economy. The spearhead of this transition will be the rapidly growing computer, semiconductor, software, biogenetics, and telecommunications industries. Growth of these industries will require an extraordinary expansion of research and enrolment (e.g. at least a tripling of engineering graduates in the United States). The title of the book comes from the notion that the purported transformation of industrialism will occur in a highly competitive world economy, and those nations which do not make the necessary adjustments will become economic backwaters, with resultant declines in living standards and quality of life.

The general theme of this book is not new. Futurists have been presenting us with visions of the knowledge society for quite some time, and the authors make appropriate reference to Bell, Machlup, Toffler and Forrester (though their treatment of the post-industrial and other futures literature is pretty scanty). Their main contribution is more in eschewing abstract scenarios, and instead presenting hard evidence and case study of the high technology developments which have occurred, and detailing the implications of such developments for higher education and other areas of public policy. For example, they observe that accelerated depreciation and investment tax credits may be a great boon to older, slowergrowing capital intensive industries which generate most of their capital from earnings, but not as effective as lower capital gains taxes and R\&D tax credits for fast-growing technology firms that look to the market for start-up and expansion capital and are dependent upon high-risk investments in R\&D. (They question the judgment of a government which gives a billion dollars of public financing to Chrysler Corporation while making high technology firms compete for overpriced capital on the open market).

A chronic weakness of all the literature on the high technology boom with which I'm familiar is the inability to produce a satisfactory definition of high technology. This book is no exception. For the most part, the authors equate high technology with the computer, semiconductor, and related software and electronics industries. At one point, they define high technology as "the application of science to products that are at the state of the art in terms of function and design", but they make no attempt to operationalize this definition. They ignore the possible high technology elements or developments in older industries, and tend to dismiss industries like transportation equipment, metal fabrication, and textiles as "sunset industries". But surely some consideration must be given to the fate of these industries in any national economic strategy. Another weakness of the book is that it is not well written, and that fact will likely lessen its impact upon the academic community and limit the extent to which members of the academic community would wish to be identified with it, however much they are gratified by its conclusions and recommendations. For example, there is much just plain bad sentence construction: "of the top ten U.S. R\&D companies, all are in the information technology industry in terms of the percentage of sales allocated to R\&D activities". Readers will wince at sentences like "Reagan's 
efforts to strip away fat may end up bleaching higher education to the bones". It would be unfortunate, however, if the arguments in the book are ignored as a result of such prosaic misdemeanors. In fairness, my impression is that the authors wrote the book in a hurry, both because they felt it urgent to get their message to the public and because they are quite busily involved in consultative and leadership activities of the kind which they are writing about. One of them, for example, is founder and President of an information technology company, and founder of the Massachusetts High Technology Council.

In my view (and I am still one of those people whose home has not entered the electronic age), the vigourous style, experiental reporting, and volume of data which characterize this book more than make up for any deficiencies in writing. These are some of the observations about high technology industry which the authors present: the marketplace for electronic goods, from chips and microcomputers to optical cables and electronic battlefield equipment totalled $\$ 105$ billion in 1980 , and $\$ 140$ billion in 1982 . By 1985 , it is expected to be $\$ 205$ billion, or the equivalent of 30 million cars. Information technology industries are already larger than the auto industry, and are projected to be second in size only to the energy industry by the end of this century. In just a few years, Japan captured 40 per cent of the market for $16 \mathrm{~K}$ dynamic RAM (random access memory) chips. The next round of competition is for the $64 \mathrm{~K}$ chip market, and Japanese industry has captured an early lead with 70 per cent of the market, and appears, with substantial help of its government, to be way ahead in the development of the $256 \mathrm{~K}$ chip. Between 1980 and 1985, sales of small, portable computers in the United States are expected to grow from $\$ 945$ million to $\$ 6.5$ billion. In Massachusetts, employment in high technology industry nearly doubled between 1958 and 1978, while declining by 5 per cent in the rest of manufacturing industry.

The authors' main concern is to document the present deficiencies of American education from the perspective of what is needed to prevent high technology industries from "going the way of Detroit". Much is made of comparison with Japan. On a per capita basis, Japan produces nearly triple the number of electrical engineers as does the United States (the latter is way ahead in production of lawyers). Two of five master's degrees in Japan are in engineering, compared to one in twenty for the United States. The percentage of students in engineeringbased higher education is 6 for the United States, compared to 21 for Japan (and 37 for West Germany). Half of Japan's senior civil service hold engineering degrees. There has been a 10 per cent reduction in master's degrees and a 48 per cent reduction in Ph.D.'s in electrical engineering in the United States since 1970.

According to the American Electronics Association, the need for new computerrelated Ph.D. graduates in industry and academia totalled 1300 in 1979. Yet only 190 doctorates in computer science were granted that year in the entire country, and the number fell to 159 the next year. According to the American Society of Electrical Engineers, nearly 50 per cent of faculty positions in solidstate electronics, computer engineering, and digital systems were vacant. The 
university research situation is said to be precarious also. About 80 per cent of university research is carried out in 100 leading research universities which derive 70 per cent of their research funding from federal sources. The authors document Reagan's massive cuts in science and engineering funding, such as the cut in the National Science Foundation science and engineering component from $\$ 70$ million in 1981 to $\$ 15$ million in 1983 . They note the irony (and perversity) of Reagan's plans to spend $\$ 1,600$ billion on defense over the next five years, while at the same time undercutting the scientific and engineering base for much of the planned growth in defense spending. (Incidentally, one of the most interesting chapters in the book is the one on defense priorities, which shows the conflict between the Pentagon's emphasis on the development of VHSIC (very high speed integrated circuits) and the commercial electronics industry's emphasis on VLSI (very large scale integrated) circuits.) The deplorable state of science and mathematics education in American high schools is examined lightly. What is more noteworthy than statistics on declines in test scores and participation in math and science courses is the anecdote about the electronics teacher, laid off from a silicon valley high school in a round of budget cuts, now doing training for electronics technicians in a nearly semi-conductor company. The authors do not say whether the trainees include drop-outs from the high school, but, if so, that experience would seem to be an apt metaphor for the educational response to the high technology challenge.

It goes without saying that one of the authors' recommendations is for a major expansion of science and engineering education in U.S. higher education. They estimate that about $\$ 500$ million a year is necessary to fill current vacancies; increase faculty salaries to levels competitive with industry; provide adequate graduate fellowships; maintain physical plant; and provide state-of-the-art equipment. This is said not to be "excessive" when compared to the $\$ 1,600$ billion (five year) defense budget. They urge also more effective lifelong learning in a field where the estimated half-life of technical knowledge is about five years. The major recommendations, however, are for a national commitment to and national strategy for making the U.S. the world leader in high technology industry, including making the direction of these efforts a personal priority for the White House; and the development of collaborative partnerships of federal, state, and local governments with industry and educational institutions under the umbrella of new federal legislation that is referred to as a "high technology Morrill Act". They describe numerous examples of such initiatives, ranging from the Microelectronics Center of North Carolina, which received a $\$ 24$ million start-up grant from the state and which will result in a 50 per cent increase in graduate enrolments in electrical engineering and computer science in the five affiliated universities in the first year alone; to the instructional television program at Stanford University which reaches 44,000 engineers at their places of employment in the silicon valley and brings the university a million dollars in revenue above basic tuition fees. 
The authors are mildly optimistic about the ability of universities to adapt to the challenges which they describe, citing, as I've noted, numerous examples of successful initiatives, and including at the end of the book encouraging statements by several Presidents of leading universities (as well as of corporate leaders). They note, without suggesting whether it's the wave of the future, the establishment of the Wang Institute of Graduate Studies on the idyllic Massachusetts campus of a former theological seminary, because the Chairman of Wang believed that traditional academia could not do what he felt needed to be done. Their treatment of the legal and philosophical issues in university-corporation partnerships is shallow, but they quote the Harvard administrator who remarked that "what we want is to get pregnant without actually losing our virginity". They do, however, demonstrate a particular sensitivity to the potential conflict between massive re-orientation of higher education to the industrial and employment demands of high technology industry and the university's traditional mission. Concern is expressed about the growing chasm between the humanist and technologist, not only through competition for dwindling resources, but also arising from differing visions of what a university should be. Stanford University put a cap on its engineering department at 1800 students, because its President feared that without such limits humanities would be undersupported and technology education over emphasized. The President of Grinnel College is quoted, claiming that liberal education is "in danger of obliteration as technical and vocational studies expand to meet the demands of the marketplace". The authors urge more integration of science and humanities education: "humanities education needs to concentrate more on employability of graduates without compromising the traditional goals of intellectual development ...... and technically oriented people need - even if they don't always want - a broader education to stimulate their intellectual development and to sharpen their communications and conceptual skills". It is noted that engineering schools have gone further in requiring humanities courses than liberal arts schools have gone in incorporating computers and science. MIT, for example, requires that 20 per cent of an engineering student's courses be in humanities and social sciences. The authors give plaudits for academic programs which incorporate social values into scientific study popularly known in the United States as STS (Science, Technology, and Society) programs and courses, and describe several such programs. At best, such programs may increase the sensitivity of a few future scientists to the social impact of technological development and give non-scientists greater appreciation and understanding of where science is going (and possibly arm a few future Ralph Naders). Apart from enhancing communication between the two cultures (the value of which is not to be denied), they will not tell us how to accommodate a situation where the scientific and technical divisions of our universities are being pushed toward rapid expansion, while the other areas face continued decline; or help us choose between that alternative and one of continued stagnation spread evenly throughout the university. 
When I finished reading this book, I was left with two main questions. First, did I just return from an excursion in fantasyland, and should the book be in the romantic fiction section of our libraries (if they can afford to purchase it)? The New Year's economic forecasts mostly point to continued economic stagnation during the eighties, with the major question being whether we are in for a severe Depression. In spite of Time Magazine's heralding of the computer as our new angel, no mainline economic forecasts envisage a new era of economic growth led by high technology. Perhaps we could place more faith in the Global Stakes scenario in a world where E.T. were man of the year. I am not thoroughly familiar with data on the labour market for educated manpower in the United States, but from what I have read, employment prospects for graduates are not in general very good. The leading analyst in this field, Richard B. Freeman of Harvard University, notes that even for engineering, 24 per cent of recent Ph.D. graduates reported having no specific job prospects upon receipt of degree, compared to 26 per cent for all disicplines, and only 7 per cent for engineering Ph.D. graduates ten years earlier. 'However, he notes also that the market in technical areas is the best that it's been in years, as engineers are hungrily wooed with salary offers reaching $\$ 30,000$ while liberal arts graduates scrape to find jobs at $\$ 12,000$. Perhaps students foresee the high technology boom, as nearly 17 per cent of freshmen list engineering as their intended occupation, compared to 8 per cent in the mid-seventies, which was down from 16 per cent in the mid-sixties. Unemployment of Ph.D.'s, or underemployment, has reached such proportions that there have been several major studies of the phenomena in the United States recently. The most comprehensive of these studies ${ }^{2}$ focusses mainly on the problems in the humanities, and is temperate about the claims of imminent shortages of $\mathrm{Ph} . \mathrm{D}$.'s in technical fields: "the situation is critical for humanists .... . but is serious for scientists and engineers as well"; and it concludes elsewhere that "projections of future demand for more Ph.D.'s are uncertain at best". Could it be that those who are caught up in the current mood of enthusiasm over high technology in the U.S. are erroneously generalizing the dramatic experience of a few industries to the entire economy, and that the employment demand generated by these industries won't have much impact on the aggregate level of employment opportunities, even within the science and technology fields, for university graduates?

The other question I have about this book is its relevance for the Canadian economy and Canadian higher education. I could find only one reference to Canada in the book (half a chapter is devoted to France and several pages to

1. Richard B. Freeman, "Response to Change in the United States", Robert Lindley (ed.). Higher Education and the Labour Market. Leverhulme Programme of Study into the Future of Higher Education, No. 1. Society for Research into Higher Education, Guildford, Surrey, 1981, 86-119.

2. Lewis C. Solmon et al., Underemployed Ph.D's. Lexington Books, D.C. Heath and Company, Lexington, Massachusetts and Toronto, 1981. 
Brazil). That was in a paragraph dealing with computer-assisted education, and the uses of videodisks and micro-electronics in education. Yet it is not hard to imagine a similar book being written in a Canadian perspective and being promoted by Canadian engineering and science educators. Indeed, a vision of an industrial future similar to that in Global Stakes seems to underlie the Dodge Report and recent statements from the Science Council of Canada. Insofar as Canadian high technology companies, educators, and science agencies share this view of our industrial future, it would be quite useful to see a similar undertaking in a Canadian context - and one which goes further in documenting aggregate employment and educational requirements. While one should be appropriately hesitant to recommend Canadian replication of U.S. studies, we could do worse than to have our own version of Global Stakes. We are after all players in the same global poker game. High Technology may be the salvation of Canadian higher education. But before betting our (random access memory) chips on that hand, we need a whole lot better information than exists at present. 